\title{
Spirituality Manifested in the Rhetoric of Saint John Paul II
}

\author{
Maria Luisa A. Valdez* \\ Batangas State University, Philippines
}

*Corresponding Author: Maria Luisa A. Valdez, Ph.D., Batangas State University, Philippines.

\begin{abstract}
Modern technology allows humans to be more autonomous and self-sufficient, putting into question man's confidence in himself and in the spirit of the human condition which is rooted in interdependence. This situation spells a requisite for serenity in faith in God and everything else in the spectrum of human relationships. As Pontiff, John Paul II addressed humanity's questions within the standpoint of man's spiritual character, and this study analyzed the defining aspects of his spirituality as manifested in selected works and highlighted the rhetoric employed to unveil its implications on others. Analysis revealed that John Paul II's early-life experiences, his devotion to the Blessed Virgin, to Polish Saints, and Christ's life and passion on the cross were integral and causative factors which shaped his spirituality. His eloquence mirrored history's greatest leaders, with distinct tone and approach. His leadership transcended religious barriers, and his legacy as a modern-day saint was defined by the rhetorical mastery in his words and spirituality manifested in his actions which left enduring implications on Catholic spirituality.
\end{abstract}

Keywords: Catholic Spirituality, Saint John Paul II, Spirituality, Rhetoric, Vicar of Christ

\section{INTRODUCTION}

The turn of the century emergence of life-changing advances and innovations in science and technology altered human lives in ways that challenge man's confidence in himself and in others: the very autonomy being offered by state of the art gadgets available to people may have unprecedented implications that undermine human nature's need for introspection and healthy relationships with other human beings. Today's time seemingly cries for man to question his confidence in others as well as in himself, and spells a requisite for serenity in faith not limited to a Supreme Being, but likewise is inclusive of faith in oneself and in the existence of others. It is with this kind of faith that builds bridges by teaching man the importance of other people. It is with faith that man gives importance to the whole of existence by not negating everything that is happening around him as mere spontaneous and unimportant events. Faith guides him to consider every bit of event as part of a whole, and with this level of thinking, faith empowers man to achieve a better understanding of life.

While the meaning of life has long since been pursued by man, his questions about life spell his oneness with the rest of humanity, as the pursuit of life's meaning entails a necessary questioning of love, truth, sorrow, the existence of a Supreme Being, redemption, peace and calm, chaos and violence, and everything else in between that may be considered facets of human relationships. As leader of the Catholic Church, Pope John Paul II afforded the faithful with answers that addressed humanity's questions while giving emphasis to the importance of the spiritual aspect of man's very behavior, character and existence. Spiritual awakening, to St. John Paul II, is within the purpose of man's being.

Spirituality brings with it various meanings to various people who aim to define it. Catholics, for example, ascribe the meaning of spirituality to the testimonials, writings and works of saints and other relevant Christians throughout the history of the religion's existence. To others, spirituality translates to one's pursuit of the state of being holy[1].

Conversely, spirituality is not limited to merely being sought by man in the midst of the hustle and bustle of life, rather, spirituality has everything to do with man's dealings with himself and others. In essence, spirituality refers to how man lives his whole life under the grace and influence of a Supreme Being[2]. Spirituality is within man's understanding that in life, there is much more than what meets the eyes. If a common marketing tagline tries to convince man to accept that what he sees is what he gets, spirituality gives man the opportunity to get more than what he sees. A spiritual life permits man 
to have an insight that is out of the ordinary, and provides for man an additional breadth in understanding what a non-spiritual person may deem common or ordinary. The understanding afforded to man by spirituality brings forth a whole new dimension to life, rendering him greatly aware to life's mysteries and wonders that thrive in his surroundings.

The existence of this level of spiritual awareness is innate to humans, but requires one to be in pursuit of it and to be subjected to a strict discipline in order for him to uncover or reawaken the self to this depth of spirituality. It may be considered utterly demanding for one to pursue spirituality, and may, necessitate a paradigm shift, yet it can never be denied that the main goal of the pursuit of spirituality is for man to attain a level of consciousness that empowers him to view life from a better perspective. With spirituality, man achieves a rediscovery that helps him understand the centrality of God's existence in his very core.

The late Catholic Pontiff John Paul II was highly revered even by people from other faith, his life and works are yet to be understood fully as rarely has it been that a non-Christian scholar out rightly proclaimed the Pope's life as an essential source of information with respect to John Paul II's spirituality [3]. However, much can be understood from Pope John Paul II's messages on spirituality, in his contention of the meaning of life, and in his aversion to the observation that people wander aimlessly, oblivious to life's true essence. To those people, Pope John Paul II offers a way to ascribe meaning into their lives; by way of devoting their lives to loving their neighbors, their community, to humanity as a whole, while not negating the need to devote a life in pursuit of a deeper purpose.

Pope John Paul II aimed to detangle the threads that bind life to all its complexities and strove to lead people to the more righteous path of true faithful. He encouraged men to trudge the right path no matter how hard the journey, and this very basic message he highlighted with the spotlight on spiritual awakening as the defining factor of the purpose of life. Pope John Paul II showed a deep understanding of his personal relationship with God, as well as his relationship to the rest of mankind.

The value and meaning of life is capable of being discovered and understood if one does not fail to notice the simplicity and beauty of this pursuit through a spiritual journey, where living is the purpose of being, and death is a necessary part of life that connects one to the realization of his existence. In the Holy Bible's New Testament, John's second book in Chapter I verse 6 calls on man to a necessary reflection on the right way to living, and links love to the way of life that God intended man to live by. The message in the second book of John was clear: live a life of love.

While subtle, the aforementioned message was full of substance, and if one were to consider John Paul II's perspective of mankind as being and becoming journey men in the pursuit of the meaning of existence, the message of "living a life of love" proves to be significant. Thus, this study aims to reawaken, and redirect people toward a reinstatement of a more purpose-driven pursuit of the meaning of human existence. With John Paul II as beacon, this study hopes to shed luminance to the otherwise obviously obscured role of spirituality in life.

John Paul II in his life as a pontiff was the chief articulator of the Catholic faith, and belonged to the greatest Catholic minds of the 20th century. Not only was his papacy one of the longest in Christian history, but also was considered one of the most productive. John Paul II was a natural educator, and after serving as the Head of the Catholic faith which he assumed in a crucial moment in history, he left behind a legacy of a vast amount of literature which includes official papal documents, literary works, personal writings, essays, memoirs, teachings, and academic works along with his papal audiences and public addresses. The enormity of the body of work John Paul II left behind as a legacy is yet to be assessed as to the extent and the erstwhile implications his work will have for the future generations [3].

John Paul II, with the sophistication in his works, his discourses and his conversations with the greatest thinkers of today's time, was truly a man of mysticism, he speaks God's language with the necessary eloquence while being nourished by the memories of his youth which served as the starting point of his spirituality, as with every unique life experience which served as the fuel that kept his fire ablaze [4].

Barnes and Whiteney (2015) [5] offer a testament to anyone who wishes to understand Pope John Paul II's message, that for one to unveil the truth about the pontiff's motivation, one must return to the former Karol Wojtyla's Polish roots. This paper likewise aims to analyze the relationship of the late 
Pope's major papal themes to important events in his life in Poland: his vision, vocation and the life and home he left behind to become the Holy Father to millions of people.

As Christ's vicar and being among St. Peter's successor, Pope John Paul II was a pope of the contemporary times. He revolutionized the papacy by taking his mandate from the confines of the papal office in Vatican and out into the world. He was, in a real sense, the first globally oriented pope [6]. He traversed continents and conquered global audiences with his message of religious freedom, and the way he endeared his papacy to people from all over the world paved the way for a successful propagation of the Catholic faith. He was Christ's vicar, God's representative, and the Catholic Church's foremost authority, and yet he exuded a life that endeared him to masses. The immense weight of being the Catholic faith's torch bearer did not keep him from showing the world that holy as he might have been, he was a man who appreciated the Swiss alps, poetry, music, designer robes, and more importantly, education [5].

Being the pope of contemporary times, Pope John Paul II was successful in maintaining his influence: he was the Pope who triumphed over communism; he relentlessly called for the reconciliation of Jews and Christians, and raged against the evil in contemporary "culture of Death". His stand on sensitive issues, no matter how diversified, earned the people's respect for being uncompromised and consistent. He might have been labeled by detractors as infuriating, stubborn, old fashioned and indifferent, but his limitations were overshadowed by the immensity of his accomplishments, all of which might as well be attributed to the motivation brought about by Karol Wojtyla's Poland of old [5].

John Paul II exuded a life of holiness thoroughly absorbed in an intimate relationship with his Creator, with his Redeemer. But he lived his life in a way that did not let him become detached from the faithful that he loved most. He was considered a man of great intellect and a charismatic figure who was adept in endearing himself to the people. He was loved by the people that upon his death, crowds chanted "Santo Subito" in unison, perhaps sensing the inevitable sainthood of the late Pope [3].

Pope John Paul II's teachings offer a fresh perspective on spirituality and faith, not entirely as a byproduct of theological insight but rather, and more often than not, rooted in his own life experiences. Now that the former vicar of Christ is officially among the ranks of the Catholic Saints, it is worthwhile to reflect on the Pope's spirituality in connection with the life that he lived amongst most of us, for much can be gleaned from the life of Pope John Paul II if his personal life and the larger the role he served in his lifetime were to be considered in the context of the Saint's innermost spirituality.

The insights that can be gleaned from the legacy of Saint John Paul II's selected works and the wisdom behind all of it are but few of the motivating factors which may convince the Filipino people to reexamine the lives they led and this process follows a genuine awareness of the Saint's unique spirituality. His works are full of thought-provoking insights that could redefine the Filipinos' spirituality as vital factors in nation building: his words are rich in messages that Filipinos will be able to understand, thus, the connection between the Filipinos' specific religious practices and spirituality can be understood as interlinked. Thus, the Saint's selected works may well serve as modifiers of human acts, specifically in behavior, character and motivation, all of which are necessary for the Filipino's development as a person that is part of his society. With these thoughts in mind, the researcher deemed it necessary to analyze the spirituality of Saint John Paul II as reflected in his selected works; to identify the rhetoric used by the Saint to unveil his spirituality, and to gain honest and genuine implications of his manifestations of spirituality on Catholic spirituality.

The value of undertaking literary analysis can be outlined based on its particular relevance to a certain number of individuals: to members and managers of the academe who may consider the abundance of virtues in Catholic spirituality that will prove essential to their respective academes; to practicing professionals who may be willing to learn how the usage of language in a provocative context may be able to contribute to the study of spirituality; to university professors and college instructors of literature who may learn from the application of appropriate concepts and approaches in literary analysis; to students of literature who may experience a rediscovery of appreciation of literature as a notable work of art with its unique quality of form and content that is unlike other texts, thus inspiring them to consider literary analysis as a beneficial activity; to literary fans, enthusiasts and aspiring writers who compose the ever-progressive generation of social and philosophical theorists by virtue of the connection of spiritual concepts to pedagogical applications that may provide the necessary fuel to 
the machinery aimed at society's improvement and spiritual rebirth; to the researcher who will particularly benefit from this study in the light that it will serve as her modest and sincere contribution to the ever-growing body of literature on spirituality; to future researchers who can benefit from this paper which may serve as a framework for future studies in exploring the efficiency and efficacy of literature as form of communication.

Bearing these thoughts in mind, the researcher who is currently a professor of literature at the Batangas State University felt deeply motivated to undertake, explore and engage in an analysis of spirituality manifested in Saint John Paul II's literary works.

\section{OBJECTIVES OF THE STUDY}

This study offered an analysis of the primary defining characteristics and aspects of the spirituality of Saint John Paul II as manifested in his selected works. This paper likewise deemed it fit to highlight the rhetoric employed by Saint John Paul II to unveil his spirituality and the implications of Saint John Paul II's manifestations of spirituality on Catholic spirituality.

\section{Methods AND MATERIALS}

\subsection{Research Design}

This paper utilized the method of qualitative analysis in studying the spirituality of Saint John Paul II as manifested in his selected works. Qualitative approach gives merit to the multiple realities that are afforded to the readers in understanding the complexity of a phenomenon. This premise, according to Suter (2012) [7] forms the philosophical framework of qualitative research. Speeches, discourses, dissertations and written work are but few examples of literary genres that provide multiple reality experiences to readers. In consideration with the previous principle, philosophical and historical approaches were likewise used as analytical bases in this study.

With their meaning having sprung forth from social, cultural and political influences, human experiences are considered intertwined, closely attached and are therefore directly related to the said influences, according to Ary, et al. (2006) [8].Hence, in analyzing the selected literary works of Saint John Paul II, the principles in the context of being the spiritual leader of the Catholic Faith were considered as they provided the foundation for the late Pope's motivation.

According to Patton (2002) [9], the identification of emerging patterns, concepts, themes, insights and understanding is the prime goal of qualitative data analysis. Textual analysis, a systematic technique in message content analysis and message handling (McMillan, 2000) [10] was also utilized in this research, wherein data analysis revolved around the search for patterns and the extraction of meaning from the late Pope's selected literary narrative or image data.

\subsection{Treatment of Materials}

The researcher considered the essential features in the treatment of materials in the course of this study. As it is with other forms of art, literary analysis is bound by a set of principles. Literature has a set of attributes, such as universality, permanence, suggestiveness, intellectual value, spiritual value, style and artistry by which all processes of evaluation are based upon, according to Garcia, et al. (2000) [11].

The analyzed passages from the selected works of Saint John Paul II manifest a high degree of universality due to the timeliness of the message therein, which dealt with fundamental truths that are applicable to universal conditions which appeal to everyone. The said selections exhibited the attribute of permanence due to their lasting appeal and the messages that endure and transcend the ever-dynamic nature of times, providing for the audience endless opportunities for fresh interpretations and insights.

With respect to suggestiveness, the selections were noted for their ability to move or entice the emotion, evoke introspection and appreciation, among others, with the inherent charm capable of leading the consciousness to a reawakening.

The selections' intellectual value lies within their capacity as thought stimuli, which, through a realization of spirituality and faith leads to a heightened state of mental awareness. Likewise, the moral messages within the passages from Saint John Paul II's works provide therein their spiritual value, with the capability of every message to inspire, motivate and enrich the audience's moral and 
spiritual values. The said selections were also noted for their distinctive style that gives the readers a glimpse of the writer's perspective, his perceptions on life, and insights on life's deepest meaning.

With reference to artistic value, the words of Saint John Paul II were undeniably much appreciated in part due to their aesthetic appeal. For much of the Catholics, Christians and even non-Christians alike, his words are definitely expressions of life in all truth and likewise, life's beauty.

For purposes that may serve this paper, the philosophical merits of the following literature were analyzed: The Post-Synodal Apostolic Exhortations of John Paul II specifically Catechesi Trandendae, Familiaris Consortio, and Reconciliatio et Paenitentia. In addition to the post-synodals, the researcher likewise included the book Varcare la Soglia della Speranza which was translated into the English language when it was released internationally as Crossing the Threshold of Hope for additional insights which may further substantiate the analysis.

Other literary works of Saint John Paul II which have undertones of his spirituality were not included in the study. Similarly, other approaches in literary criticism that may be employed in the study were excluded in the analysis.

The aforementioned formed the central framework and fundamental, twining core of this research. The meaning of the late Pope's message was rightfully gleaned, chartered and went under the researcher's lens, and were subjected to both external and internal analyses. In connection with this, the researcher exercised freedom in her understanding of every piece within the bounds of the concepts of ideology evoked in her awareness. The literary works were likewise appraised by way of analyzing the suitability of the messages to the theme, the relevance of the language to the situation and the appropriateness of the language used in the literary works under study. With respect to the depth and breadth of Saint John Paul II's spirituality, this research focused on the key defining aspects of the late pontiff's spiritual legacy.

\section{RESUltS AND DisCUSSION}

\subsection{The Primary Defining Aspects of Saint John Paul II's Spirituality Manifested in His Selected Works}

A thorough understanding of Saint John Paul II's spirituality which manifested in his works requires an integrated and causative analysis of his family background as well as historical events that helped shape the young boy from Poland into the Vicar of Christ and the Saint who lived among the faithful of the contemporary times.

\subsubsection{Spirituality Manifested in His Early Years}

One cannot simply overlook the history of Saint John Paul II's home country of Poland and the years of struggle the nation's people endured as the said aspects were integral and causative factors in the young Karol Wojtyla's spirituality. It can be noted that John Paul II, born Karol Josef Wojtyla was born to a family of devout Catholics from the small City of Wadowice in Southern Poland. The young Karol, together with his elder brother, was raised by faithful parents in a small abode right next to the city's parish church. It can be gleaned from his family background and the circumstance of his youth that, by growing up in proximity to the Church of the Presentation of the Blessed Virgin Mary, the seeds of spirituality was sowed deep within the heart of Saint John Paul II at a very young age. Growing up in an apartment within earshot of the Liturgy taking place in the church where he eventually became an altar server, the parish was, to young Karol, a second home [3].

Latter-life personal circumstances can likewise be understood as defining factors in Karol Wojtyla's spirituality: at the young age of nine, his mother passed away, and the responsibility of raising two sons fell on the shoulders of the elder Wojtyla, who was a just man who stood by his responsibility and commitment to raising his two sons to a life of living justly. The elder Wojtyla's choice to never remarry and raise his two sons alone can be gleaned as having an enormous and solid influence on the development of young Karol's spirituality, as the future pope would often see his father on his knees during his late-night prayers. His father's exemplary faith, for the young Karol, was considered by him as his first domestic seminary [3]. The death of his elder brother Edmund left Karol alone with his father and the circumstance tested the young Wojtyla's threshold of hope and faith.

Another key figure in the young Wojtyla's spiritual life was Mieczysław Kotlarczyk, who was one of Wadowice's theatrical directors who took the young Karol under his wing as a high-school theater 
actor. Also a devout Catholic, Kotlarczyk firmly believed that theater was in fact, similar to the vocation of priesthood, and likened the duty of a priest to an actor by opening up truth's realm. By learning to understand the power of words to shape history, John Paul II's spirituality was nurtured in his early years as a high-school theater actor, and it was evident in his eventual role as pope, where he wrote that the world is the primary dimension of a life of spirituality, and the literary or linguistic context of "word" comes close to the mystery that is the "Word" in liturgical sense [3]. Karol Wojtyla's love for theater, culture and literature was nurtured upon finishing secondary school when he, together with his father, moved to Kraków to begin university studies. However, his education at the university came to an abrupt halt upon the Nazi's invasion of Poland. The circumstances of war, however unfortunate, contributed to the shaping of Karol Wojtyla's strength of faith. A life of uncertainty amidst the horror of war taught the young Wojtyla to adapt, and to avoid being shipped to labor camps, Karol Wojtyla chose to take on jobs that introduced him to the hardship of manual labor, and this part of his life taught him to relate to common laborers. Years of spending time working with laborers whom he considered as colleagues shaped the spirituality of the future pope, who considered his life with his colleagues as a "spiritual seminary" and a "participation in God's creativity". This event in Karol Wojtyla's life shaped his spiritual being by virtue of teaching the future pope about seeing the spirituality and dignity of others, and his early thoughts on suffering as not being the curse of original sin was born out of this circumstance. Later in his life, this spirituality would be manifested by the Pope in his magisterial teachings that were deeply influenced by his deep-seated love for his former colleagues in war-torn Poland, whose worker's rights he fought for during their years of hard labor. His experience in theater shaped the spiritual man that was to become of the future pope in a way that it brought out the charismatic figure within him, which was evident in the ease by which the Pope was able to relate to the crowds that he addressed. In the same light, the Pope was known to have recalled that his experience with the Salesian Fathers also played an important part in his spirituality.

Another key figure who helped shape the spirituality of young Karol Wojtyla was Jan Tyranowski, who, after the Nazi Gestapo took away parish priests to be shipped off to concentration camps, took on the role of being one of the few laymen who led clandestine ministries during the Nazi occupation. It was during his time as a group leader for Tyranowski's "Living Rosary" that Karol Wojtyla was taught the fundamentals of living a life of spirituality. As a member of Tyranowski's Living Rosary, Wojtyla devoted his daily life to a life of intensified prayer, as a brother in Christ who vowed to be of service to his brethren and thoughts of how to reconstitute Poland into a formidable Christian society after the war were constantly on his mind. It can be gleaned that Tyranowski was pivotal in planting the seeds of hope in the youth of Karol Wojtyla's time, and perhaps his greatest contribution to Karol Wojtyla was when he introduced the young man to Saint John of the Cross and to St. Teresa of Avila. Tyranowski understood that the said Saints' spiritual poetry would appeal to Karol's innate love for literature. Introducing Karol to the Saints' literature opened the future pope's door to a profound spirituality which led him to living a life of imitating Christ by submitting to the will of God. Although during those years the young Karol Wojtyla was certain of a future life as a theater actor, the death of his father was a decisive moment that drove him to a realization of being called for a greater cause. This, together with Tyranowski's introduction of Wojtyla to Carmelite Spirituality, and the then-archbishop of Krakow Cardinal Adam Sapieha's recommendation, solidified the barely 21 year-old Karol Wojtyla to abandon his theatrical dreams in pursuit of a life of a greater cause.

Thus, it can be gleaned that a life of circumstance shaped the innermost spirituality from within the life of the young Karol Wojtyla in his early years, and his vocation which commenced in his ordination to priesthood and later culminated in his life as the successor of Saint Peter led the spirituality of Saint John Paul II to be manifested in his works.

\subsubsection{Spirituality Manifested as Inspired by Holy Personalities in His Life as a Servant of God}

To better understand the spirituality of Saint John Paul II manifested in his dealings, it is necessary to analyze the role of prominent figures that influenced the development of spirituality in his life as a servant of God.

It can be understood that the young priest Karol Wojtyla's charismatic appeal was shaped in his days spent in hard manual labor and his dealings with others were fueled by his spirituality, which taught him to accept his co-workers as esteemed colleagues who shared in his sacrifice of living a life in 
accordance with the fulfillment of God's creativity. It can also be noted that his years of studying theology while working at a chemical plant helped nourish his spiritual closeness with laborers.

Upon his ordination, the young priest was eventually sent to Rome by Cardinal Sapieha for completion of his doctorate in theology. In just under two years, the young priest returned to Poland with his doctorate and was assigned as curator in the small village of Niegowić. His reassignment to Saint Florian's Parish in Kraków as a chaplain of students in the Jagiellonian University, and his eventual completion of his habilitation thesis led him to assume lecturing duties at the university.

A pivotal moment came to the future Saint John Paul II when then-Pope Pius XII assigned Father Karol Wojtyla as the auxiliary bishop of the Archdiocese of Kraków. Then 38 year-old Father Karol Wojtyla chose "Totus Tuus" as his coat of arms, as a spiritual testament to his devotion to the Virgin Mary. Karol Wojtyla's rise through the ranks of the Catholic Church's hierarchy was undoubtedly fueled by his spiritual devotion, and culminated in his election as the 264th successor of Saint Peter on October 16, 1978 [3].

As manifested in his life as a servant of God, the spirituality of Saint John Paul II can be traced to the history and culture of his Slavic nation which he kept intact in his heart: his first mass as a priest coincides with the day Poles visit the graves of their ancestors and can be considered as a manifestation of his bond with his nation's culture and Father Karol Wojtyla likewise deemed it fit to hold mass in the very same day of what is to the Poles Dzien Zaduszny, a day of reverence to the late great rulers, bishops and cardinals who served as his spiritual inspirations.

Father Karol Wojtyla was deeply devoted to Saint John Cantius, patron of Kraków. From Saint John Cantius' life, Father Karol Wojtyla took inspiration, as can be understood in Karol Wojtyla's devotion to intellectual cultivation and love for youth, both in the context of a life of holiness, as necessary fuel to the flames of his faith and his spirituality which is hinged upon his dealings with others [3].

It can be gleaned that Karol Wojtyla saw the connection of Christian faith and the pursuit of human knowledge in Saint John Cantius, or Saint John of Kety, as Pope John Paul II's words reflected the very same message of Saint John Kety, when the Pope in 1997 alluded to the saint when he emphasized that knowledge and wisdom are in search of a covenant with holiness. This statement of then-pope many years after his ordination was a testament of his unwavering devotion to Saint John Kety, and a manifestation of his spirituality which culminated in his famous encyclical, Fides et Ratio.

Another key personality which helped shape Pope John Paul II's spirituality was Saint Stanislaw Szczepanowski who was martyred at the hand of an evil Polish king in 1079 centuries before the birth of Karol Wojtyla. Karol Wojtyla, when he was still archbishop, drew inspiration from Saint Stanislaw in his own personal efforts to oppose the then-communist government's move to limit the church authority. This can be considered as a testament of the spirituality infused within him by virtue of inspiration drawn from Saint Stanislaw [3].

Another Polish personality, Saint Jadwiga, former queen of Poland, likewise can be considered as a spiritual inspiration for Karol Wojtyla. It can be remembered that Saint Jadwiga was among those who lay in the grave when then Father Karol Wojtyla held his first mass in 1946 in reverence to the great Polish saints, but what was most notable was in 1978, when the then would be pope recalled Christ's message to Saint Jadwiga of "Fac quod vides", and connected the very same message to overcome his desire to not leave Krakow. The said message can be gleaned as a spiritual manifestation which led him to accept his role as the Catholic Faith's Supreme Pontiff.

Other modern-day saints who were spiritual inspirations of Pope John Paul II include: Saint Brother Albert, who gave up a life of an exceptionally talented painter in exchange for a life in service to the poor and homeless people of Krakow, and it was Brother Albert's choice to leave a promising life of a man of art which served as Karol Wojtyla's spiritual reinforcement and led to the Pope's playwright venture Our God's Brother; Saint Maximilian Kolbe, who provided Pope JohnPaul II a living model of priestly vocation, with whom he identified as a testimony of faith and spirituality in the life he led in great love for his fellowmen; and Saint Faustina Kowalska, who was a spiritual inspiration for Karol Wojtyla by virtue of opening his eyes to the divine attribute which was manifested in his first encyclicals as pope, where John Paul II clearly showed his spirituality in his grasp of fatherhood in the service of the Lord. Perhaps the greatest inspiration which can be considered a foremost spiritual 
figure is the Blessed Virgin Mary, who was to the Poles, not merely Christ's mother, but their nation's very own, as well. Polish culture holds Mary in high regard, as the mother of Christ is considered as protector and Queen of Poland. Major Marian shrines and the undying Marian devotion of Polish of Polish Catholics explain the deeply entrenched spiritual connection of Pope John Paul II to the Blessed Virgin. It can be remembered that after the failed assassination attempt on the Pope in 1981that he presented the bullet which was extracted from his chest to Our Lady of Fatima, and he gave the blood-soaked sash to the Blessed Mother in Czestochowa [3].

It can be gleaned Saint John Paul II's spirituality manifested in his life as a servant of God was not without inspiration from modern day saints and the Blessed Virgin. Similarly, his acceptance of his role as Christ's vicar proves that his spirituality is likewise deeply rooted in his acceptance of living the way of life similar to Jesus Christ himself, a life of love and sacrifice for his fellow men. Thus, the life he lived can be seen as not dissimilar to Christ's passion on the cross.

\subsubsection{Spirituality Manifested in Addressing Key Theological Concerns as a Vicar of Christ}

To further evaluate the spirituality of Saint John Paul II, it is of great importance to analyze the passion by which the late pontiff forthrightly addressed important contemporary and theological concerns from the perspective of a Vicar of Christ or successor to Saint Peter. Much can be insightfully gleaned from the late Pope's words, which he ardently made available to everyone in need of spiritual enlightenment.

In the years of his life as Pope, Saint John Paul II was able to compile text which he wrote to address the greatest concerns of every Christian faithful: his personal stand on the existence of a Creator; his thoughts on pain, suffering and evil; his concern for the dignity of man; and his views about the relationship of Christianity to other religions as well as that of Catholicism to other Christian sects. Much of his key messages on the aforementioned theological issues were generously provided for the faithful in the book Crossing the Threshold of Hope by Saint John Paul II himself, hence, a fruitful analysis of the saint's spirituality can never be accomplished without considering his personal handiwork.

Pope John Paul II's faith on the existence of God is hinged on his spiritual fortitude. To him, the question of God's existence is often given either in a state of hope, anxiety, or a mixture of both. With faith in his spiritual foundations, he mirrored the very message Christ himself said to many souls $\mathrm{He}$ encountered, and the very same message was echoed by John Paul II at the onset of his Pontifical role. "Be not afraid!" Pope John Paul II echoed the words that Christ Himself said, and cited that the words which were profoundly rooted in the gospel were not words that were simply resounded by the Church into a void[12]. To him, the very words of Christ were directed to the faithful, asking them to dispel all fear when it comes to faith in God. Saint John Paul II emphasized that every time faith in the Supreme God comes into question, Christ's message of not being afraid comes at the expense of all doubt in every believer's heart. Clearly, Pope John Paul II intended to send his message in the very same light, that in order for the faithful to find the answer, he must turn away from fear itself and return to his spirituality which will make him understand that Christ gave His simple message with both God and man in mind, and the existing relationship between the two, in full perspective [12].

Pope John Paul II's thoughts on pain, suffering and evil were likewise manifestations of his spiritual fortitude. Pain, suffering, and evil are sensitive theological concerns in the sense that the said concepts cast a shadow of doubt in the omnipotence of a Supreme God. The question of why God allowed suffering to persist has always been a strong argument for non-believers, and yet, Pope John Paul II addressed the concern on suffering with much confidence in his spirituality. He maintained that God Himself might be viewed as paying the price for bestowing the gift of human freedom, but essentially enough, remained consistent in His gift, placing His own self before the judgment of man [12]. Pope John Paul II said that the condemnation of God by man was not based on the truth, but on man's arrogance. He cited various examples of man's failure to realize the truth which resulted in numerous injustices wherein the dignity of man was trampled upon and lives of innocent people were taken [12].

Pope John Paul II contended that God will always be on the side of suffering, and he believed that if the passion of Christ had not culminated on the cross, the truth that God is love would have never been known to man [12]. 
His views on the relationship of Catholics to people of other religions were clearly resounded in his affirmation of religious freedom. To Pope John Paul II, while it is a revealed truth that "There is salvation only and exclusively in Christ" [12],he said that the message of the centrality of salvation cannot be understood by being limited to the physical variable that is the living body of the Catholic Church [12]. His Holiness expressed his spiritual breadth when he said that while the Catholic Church might have been bestowed the gift of salvation, it rejoices when other Christian communities share in the work of preaching the Gospel. Hence, to Pope John Paul II, the statement of non-salvation for those outside the Catholic faith is an open doctrine, not to be mistaken as ecclesiological exclusivism [12]. His message on the Catholic Church being open to dialogue with other Christians as with other non-Christian followers was a manifestation of his spiritual strength which further solidified his faith in the good nature of man, regardless of religious belief. This manifestation of Pope John Paul II's spirituality is echoed in his message on the challenge facing the faithful to increase the awareness or the value of religious freedom for society and his call to defend religious freedom against being taken away from public domain [13].

Pope John Paul II's acceptance of the role as Christ's Vicar allowed him the necessary venue to manifest spirituality in living the way of life similar to the life Jesus Christ himself lived. A life of spreading the word and generously reaching out to people regardless of faith not dissimilar to Christ's passion on the cross was a life of sacrifice the Great John Paul II left as a lasting legacy, and his words that remain consistent with the work he did as successor of Saint Peter can be easily gleaned as a solid manifestation of his deep spirituality.

\subsection{Rhetoric Used by Saint John Paul II in Unveiling His Spirituality}

In his years as a Supreme Pontiff, Saint John Paul II produced a vast amount of spoken and written literature in various forms which include the Papal magisterium, wherein rhetoric was often utilized to a certain degree which does not necessitate an invocation of the effect of infallibility of pathos, yet the authority afforded by ethos defined the success of his teachings; the encyclicals which were prime examples of the power of rhetoric in a formal and authoritative manner; documents and speeches addressed to the general members of the Catholic faith either as the Archbishop of Rome or as Head of the Faith which were delivered in a more informal manner but essentially intended to assimilate the teachings of the Gospel. Pope John Paul II's "Crossing the Threshold of Hope", for one, offers a prime venue for his rhetoric. As with all other literature attributed to the Saint, the book provided its readers answers to theological concerns in the personal style of Pope John Paul II's use of suitable language to the themes and in the typical citing of passages from the Holy Bible to further illustrate his point. It can be noted that in the book, while the Pope speaks to his audience as the Head of the Catholic Church, the delivery of his message was more personal and less authoritative. In contrast, the postsynodal exhortations that were published by the great pope offer more technical overview on the Pope's rhetoric. As compared to the authoritative grade utilized by the Pope in a regular magisterium, the Pope, who used the said exhortations in collaboration with each synod's inputs, utilized rhetoric in every post-synodal exhortation in a more deliberate and definitive manner. While each post-synodal exhortation comes with it contributions from the Bishops by virtue of their Episcopal duty [14], it can never be denied that the Pope, who affixes his papal stamp on every published exhortation, affixes his personal signature as well, and never was a post-synodal apostolic exhortation bereft of the Pope's unique rhetoric. While not entirely being exclusively a papal statement in comparison to encyclicals and apostolic utters, post-synodal apostolic exhortations were still under the papal authority and thus, by virtue, were technically considered under the papal magisterium, and rightfully so, offer great examples of the rhetoric of Pope John Paul II from within the ranks of bishops. In essence, the Pope's usage of ethoscan easily be understood as utilized by him more in other forms of papal doctrines, specifically on matters concerning faith and/or morals. In fact, none of the statements issued by the Pope in his most authoritative manner were gleaned in any of the post-synodal documents under his pontificate. Examples of such work which showed the most authoritative manner of delivery were the Veritatis Splendor which was issued in 1993, Evangelium Vitae in 1995 and the apostolic missive Ordinatio Sacerdotalis which was issued in 1994, all of which were published with the Pope using the more formal and definitely authoritative rhetorical approach of the encyclicals [14].

In Catechesi Trandendae, the Pope emphasized that the foremost goal of catechesis is not only to maintain the connection of the people and the church, but even more so to establish intimacy with Jesus Christ. He explained that the heart of catechesis is Christ himself, and added that living the life 
of Christ consists in following the Sequela Christi, thus affirming the Christocentricity of his rhetoric [14]. It can be understood that the Pope, while anchored on the ethos of his authority as Pontiff does more with the effect of pathos in mentioning the life lived by Christ himself to effectively drive his point. He also made mention of the phrase "mystery of Christ" in reference to the life, death and resurrection of Jesus Christ, the phrase "paschal mystery", which encompasses the whole of Christ's life which he enumerated in detailed actions of the living Christ as a human being, and the symbolism of the "cross" which he utilized to signify the events included within the Passion of Christ. The aforementioned examples in Catechesi Trandendae can be gleaned as clear and valid proofs of the Pope's expertise in the usage of rhetorical and literary devices to send his message.

It was typical for Pope John Paul II to quote a biblical passage from which insights can be lifted to illustrate his point, as he did in Familiaris Consortio in 1981 where ethos, logos and pathos became heavily responsible for him to establish the foundation of his message on conjugal love, with lifted text from Genesis 1:3, Matthew 19:1-9 and Ephesians 5:21-33 [14]. In it Pope John Paul II used the phrase "fruits of reflections" in reference to the proposals submitted by the synod Fathers after labored deliberations [14]. His use of the word "Church" was common with leaders of the faith, a universally accepted figure of speech which clearly gives proof of the manner by which the late pontiff comfortably but firmly grasped the efficiency of persuasion afforded by rhetoric.

The same can be said for Reconciliatio et Paenitentia, where the Pope alluded to the older brother in the Parable of the Prodigal Son in Luke 15:11-32 to deliver his point in dissecting the meaning of sin and reconciliation [14]. As with majority of his works, the Pope's citation of text and passages from the Holy Bible afforded him the necessary room to move to and fro while being contained in the topic he wished to discuss, which was about penance and reconciliation in commencing the healing process and the resolution of conflicts. The Pope's encompassing use of Pope Pius XII's phrase "sin of the century" and the tone of persuasion with the use of the phrase "sense of sin" [14] effectively showed the Pope's experience in appealing to the conscience of the moral majority.

In Crossing the Threshold of Hope, the Pope utilized flashback in numerous occasions, but the ease and comfort by which the Pope utilized the literary device can best be noted in the way he addressed the rather sensitive topic of his stand on Islam, and the Prophet Muhammad in the Chapter "Muhammad?"[12] Pope John Paul II started by recalling Nostra Aetate in which he declared the church's "high regard" for the Islamic faithful [12], and added another recollection in which he encountered a Muslim faithful whose pride in declaring the greatness of Islam did not prevent him from continuing the conversation in a "friendly tone" [12]. In the same chapter, he highlighted numerous apostolic trips he made to countries in Africa and Asia and recalled fond memories of being welcomed with "great hospitality" and was accepted with "similar graciousness". He likewise made mention of his trip to Morocco for an audience with Muslim King Hassan II which he described as a "historic event" which was, to him, not merely a courtesy call but "an event of a truly pastoral nature" as a form of flashback before closing the chapter with his message on the principle of religious freedom.

As can be gleaned from the previous examples, the depth and breadth of expertise of the Pope in his rhetoric may be attuned to the same eloquence manifested by the greatest leaders of history. If there can be a particular aspect of his rhetorical style which can be considered unique to the Pope, it is in his ease and comfort in choosing the suitable language for every particular theme or style as can also be seen in his choice of either formal or informal tone, and in the authoritative versus a more personal approach be it in teaching the word of God, or sending a pastoral passage, or even in addressing the council of bishops or even in discourses with men of different faith.

\subsection{Implications of Saint John Paul II's Manifestations of Spirituality on Catholic Spirituality}

As can be understood, Pope John Paul II effectively manifested his spirituality during his lifetime, but if the implications of his manifested spirituality were to be analyzed in the context of its implications on Catholic spirituality, his life and works as a vicar of Christ should be considered primarily.

In his many productive years as the Pontiff of the Catholic faith, the great John Paul II has had published numerous literature intended to shape the consciousness of the faithful in the context of being true followers of Christ, and Pope John Paul II's legacy does not stop in the millions of followers who, inspired by him, adopted the Pope's style of infusing the words from the Holy Bible 
into every discourse, as part of the rhetoric indirectly learned from the great modern-day saint. Neither did the Pope's legacy become limited to the papal magistrates, encyclicals, and papal letters norto the post-synodal exhortations, which may have to wait for a few years in the archives before half of their essence may even be gleaned by those who will be privileged to officially dissect their message and possibly, discover fresh new undertones.

For much of the Catholics and other followers of the Christian faith, Saint John Paul II's legacy lives within, not in the physical confines of the Vatican nor in the abstract expanse that is the church, but simply, and more exactly, within each person who loved and respected him when he lived, and even more so now that he is among the saints he himself loved all throughout his life as a devout follower of God.

Pope John Paul II's spirituality afforded him the necessary vigor and vitality to trudge in the footsteps of every Polish Saint he revered, and by doing so, he trudged the path of Christ. His message of "Be not afraid", his thoughts on faith, pain and suffering, man's dignity, his personal relationship with God-none of these concepts will be able to stand the changing times if Pope John Paul II had not firmly established his legacy which was in its entirety, deeply anchored in his spirituality.

His message of religious freedom has long since been adopted by the faithful. In "Defending Our Catholic Identity", Supreme Knight of the Knights of Columbus Carl Anderson quoted Pope John Paul II's call for a unified awareness in the importance of religious freedom for society [13]. In it, he resounded the Pope's valiant call which in turn is being upheld by the Knights of Columbus, a key Catholic organization composed of devout Catholics in service to the community. The implication of Saint John Paul II's message of religious freedom, as with his other messages, is evident in ways that have traversed the Vatican, the Church, and the Catholic communities, down to each and every individual. It cannot be denied that Saint John Paul II's template of Catholic spirituality transcends religious barriers, as in the case in Morocco when he concluded a pastoral visit to a non-Christian head of state, and after which was welcomed warmly by the Muslim youth in attendance at Casablanca Stadium in 1985 [12].

Thus, it can be gleaned that Pope John Paul II was one of the most important, if not the most important Pontiff the Catholic faith ever had. He will remain the modern age's great pope who exuded charm, intellect, faith and the necessary spirituality to become the perfect cardinal to assume the role of Vicar of Christ in the most unprecedented manner. Such is the legacy of the great pontiff that right after his death, calls for his sainthood resounded. Even before he became physically weak due to his age and illness, notions of his sainthood were a staple in every devout Catholics conversation centered in his pontificate. John Paul II's rhetoric defined every word he spoke to the people as successor to Saint Peter, but not without the spirituality deeply rooted in his Polish roots and planted firmly by the young Karol Wojtyla, and the selections that were mentioned in this paper and included within the scope of this study are but a meager part of the legacy that Saint John Paul II left to the world.

He always addressed the question of God's existence with much zeal and fervor due to the immense spirituality he possessed. It is with this spirituality that he never felt dissuaded in questions about the existence of God. To him, God definitely and certainly exists. What was more of a concern to the Pope was the faith of the Lord's flock, and the question asked by Jesus Christ himself in Luke 18:8: "When the son of man comes, will he find faith on earth?" was always in the pope's mind, being a question that defined the success of a pontificate. It is without a doubt that John Paul II as a Vicar of Christ essentially addressed Christ's question and banked on spirituality to consummate his union with God and His believers. Spirituality served as Pope John Paul II's life force in his journey in following the footsteps of Christ, and by doing so, the follower became the leader to the rest of the flock, and thus, the question: "An Deus Sit?" or "Does God exist?" he was able to address triumphantly both by the rhetorical mastery in his words and in the spirituality manifested in his actions.

\section{CONCLUSION AND RECOMMENDATIONS}

Saint John Paul II's early-life experiences, his devotion to the Blessed Virgin, to Polish Saints, and Christ's life and passion on the cross were integral and causative factors which shaped his spirituality. His eloquence mirrored history's greatest leaders, with distinct tone and approach. His leadership transcended religious barriers, and his legacy as a modern-day saint was defined by the rhetorical 
mastery in his words and spirituality manifested in his actions which left enduring implications on Catholic spirituality.

Bearing these insights in mind, the researcher offers the following recommendations: that members and managers in various academic fields may learn from the insights on spirituality in this study that Pope John Paul II manifested in his work and find merit in his style of persuasion which may be applied in their particular academes; that practicing professionals may consider this paper as a learning source by which the usage of language as an effective means of persuasion may prove helpful in improving productivity and foster better working relationships within and at the periphery of their respective fields; that university professors and college instructors of literature may learn from the template of John Paul II as a leader of the Lord's flock, and that by understanding his utilization of important concepts to persuade, they may essentially find it worthy and applicable in their profession of shaping the minds of the coming generations; that students and fans of literature, through the application of the concepts within the scope of this study, may experience a renewal of enthusiasm in literature and learn from the insights gleaned in this research as worthy and motivational factors in pursuing literary analysis as a healthy academic endeavor, and; that future researchers may consider the researcher's humble contribution to the growing body of literature about spirituality as reference for future research which may augment and further substantiate this study.

\section{ACKNOWLEDGMENTS}

The researcher wishes to express her personal thanks and appreciation to those who helped make this humble work a reality. First and foremost, she wishes to thank God, for inspiring her during the writing process. To Dr. Tirso A. Ronquillo, the Batangas State University President and the other University officials most especially to Engr. Alberson D. Amante, the Vice President for Research, Development and Extension Service, and Prof. Enrico M. Dalangin, the BatStateU ARASOF Nasugbu Executive Director, for the motivation that helps hasten the completion of this study. To Mr. Thaakor Pathak, for his wisdom that drew up essential and relevant dimensions in this research. To the pool of writers whose works were included in this study for posterity, for their emboldened wisdom in every page of this research. To all of you, the researcher owes her deep gratitude.

\section{REFERENCES}

[1] Chervin, Dr. Ronda's note cited in Koliński, SJC, Fr. Dennis (2014) The Spirituality of Saint John Paul II; url: http://goodbooksmedia.com/toward-a-21st-century-catholic-world-view/the-spirituality-of-saint-johnpaul-ii; date retrieved: 04/10/2016.

[2] Shannon, William H. (1999) Anselm: The Joy of Faith. New York, USA: The Crossroad Publishing Company.

[3] Koliński, SJC, Fr. Dennis (2014) The Spirituality of Saint John Paul II; url: http://goodbooksmedia.com/toward-a-21st-century-catholic-world-view/the-spirituality-of-saint-john-paulii; date retrieved: 04/10/2016.

[4] Whitney, Helen (2014). Faith. John Paul II: The Millennial Pope; url: http://www.pbs.org/wgbh/pages/ frontline/shows/pope/etc/faith.html; date retrieved: 04/22/2016.

[5] Barnes, Jane and Helen Whitney (2014). John Paul II: His Life and Papacy. John Paul II: The Millennial Pope; url: http://www.pbs.org/wgbh/pages/frontline/shows/pope/etc/bio.html; date retrieved: 04/22/2016.

[6] Blakemore, William B. (2016).Saint John Paul II; url:http://www.britannica.com/biography/Saint-JohnPaul-II; date retrieved: 04/10/2016.

[7] Suter, W. Newton (2012). Introduction to Educational Research. University of Arkansas at Little Rock Sage Publications, Inc.

[8] Ary, Donald, Lucy Cheser Jacobs, Asghar Razavieh, Christine K. Sorensen (2006). Introduction to Research in Education. Wadworth: Belmont, California, USA.

[9] Patton, M. Q. (2002). Qualitative Research and Evaluation Methods. Thousand Oaks, California, USA: Sage.

[10] McMillan, S. J. (2000). The Microscope and the Moving Target: The Challenge of Applying Content Analysis to the World Wide Web. Journalism and Mass Communication Quarterly, 77(1).

[11] Garcia, Carolina U., Piedad G. Rosales and Corinta G. Barranco (2000) A Study of Literary Types and Forms. UST Publishing House, Manila Philippines.

[12] Paolo II, Giovanni (1994). Varcare la Soglia della Speranza. Jonathan Cape, Random House, London.

[13] Anderson, Carl A. (2012). Defending Our Catholic Identity. Columbia, Volume 92 No. 7 
[14] Miller, J. Michael (1998). The Post-Synodal Apostolic Exhortations of John Paul II. Our Sunday Visitor Publishing Division, Our Sunday Visitor, Inc. url: https://books.google.com.ph/books?id=nE36DRkST FgC\&pg=PA39\&lpg=PA39\&dq=Rhetorical+devices+used+by+Saint+John+Paul+II\&source=bl\&ots=c6y On_vaeb\&sig=SW60R_1L6rGX5BmOAOoyOLcrhnY\&hl=en\&sa=X\&ved=0ahUKEwjWn8DD5IPMAhV F4aYKHbZCCi0Q6AEINjAF\#v=onepage\&q=Rhetorical\%20devices\%20used\%20by\%20Saint\%20John\% $20 \mathrm{Paul} \% 20 \mathrm{II} \& \mathrm{f}=$ false; date retrieved 4/23/2016.

\section{AUTHOR'S BIOGRAPHY}

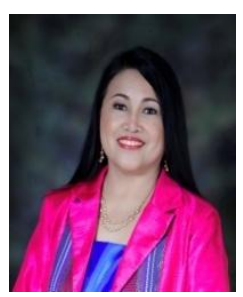

Maria Luisa A. Valdez, earned a Doctor of Philosophy degree with a specialization in English from the Batangas State University (BatStateU), Philippines. She has published several researches in reputable international refereed journals and presented papers on local, national and international research forums. Likewise, she is an editorial board member and a peer reviewer of various international refereed journals. Her research interest centers on education, philosophy, humanities and social sciences specifically on contemporary social issues like peace education, gender equality, and environmental issues manifested in the selected contemporary literary works in English. She is currently a professor in BatStateU and a visiting professor of the Thai Nguyen University (TNU) International Training and Development Center (ITDC), Socialist Republic of Vietnam

Citation: Maria Luisa A. Valdez. "Spirituality Manifested in the Rhetoric of Saint John Paul II " International Journal on Studies in English Language and Literature (IJSELL), vol 6, no. 2, 2018, pp. 1-13. doi:http://dx.doi.org/10.20431/2347-3134.0602001.

Copyright: (0) 2018 Authors. This is an open-access article distributed under the terms of the Creative Commons Attribution License, which permits unrestricted use, distribution, and reproduction in any medium, provided the original author and source are credited. 